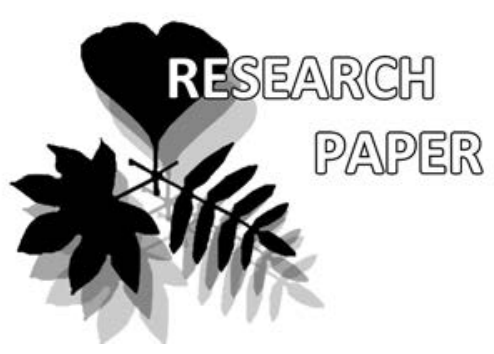

\title{
Ecological diversity of algae in the Alakol Lake Natural Reserve, Kazakhstan
}

\author{
Aibek Jiyenbekov ${ }^{1}$, Sophia Barinova ${ }^{2 *}$, Aitkhozha Bigaliev ${ }^{1}$, \\ Satbay Nurashov ${ }^{3}$, Elmira Sametova ${ }^{3}$ \& Tzion Fahima ${ }^{2}$
}

\author{
Aibek Jiyenbekov ${ }^{1}$ \\ e-mail: zh-ai-bek@mail.ru \\ Sophia Barinova ${ }^{2 *}$ \\ e-mail: sophia@evo.haifa.ac.il \\ Aitkhozha Bigaliev ${ }^{1}$ \\ e-mail: aitkhazha@gmail.com \\ Satbay Nurashov ${ }^{3}$ \\ e-mail: nurashs@mail.ru \\ Elmira Sametova ${ }^{3}$ \\ e-mail: elyasam@mail.ru \\ Tzion Fahima ${ }^{2}$ \\ e-mail: tfahima@evo.haifa.ac.il
}

\author{
${ }^{1}$ Al-Faraby Kazakh National University, \\ Almaty, Kazakhstan \\ ${ }^{2}$ Institute of Evolution, University of \\ Haifa, Israel \\ ${ }^{3}$ Institute of Botany and \\ Phytointroduction, Almaty, Kazakhstan
}

\section{* corresponding author}

Manuscript received: 16.01.2019 Review completed: 12.05.2019 Accepted for publication: 14.05.2019 Published online: 20.05.2019

\begin{abstract}
A B S T R A C T
Alakol Lake is a unique protected natural water body with a gradient of salinity in which algal diversity has never been studied before our research. We revealed 208 algal species from five taxonomic Divisions during 2016-2017 studies. Diatom species were strongly prevailing in the 29 studied communities of the lake. Statistical methods revealed a high correlation between the intensity of algae development and the number of species in the community, as well as the high individuality of the algae communities at the three studied sites on the CCA. The applied analysis of the distribution of taxonomic divisions and indicator categories using statistical maps showed that euglenoid species, which mostly correlated with organic matter input, are distributed in the lake from the Rybachje settlement. A mapping of bioindication groups revealed an influence of hidden and inflowing rivers Urzhar and Zhamanty as sources of organic pollution. This conclusion can be made on statistical mapping only in addition to bioindication results because environment variables usually are limited. This assessment of protected lake can serve as a reference for future investigation of the Alakol Lake as well as can help to plan a set of stations for monitoring.
\end{abstract}

K e y w o r d s : algae, bioindication, CCA, ecological mapping, organic pollution, Alakol Lake, Kazakhstan

\section{P E 3 Ю M E}

Ажиенбеков А., Баринова С., Бигамиев А., Нурашов С., Саметова Е., Фахима Т. Экологическое разнообразие водорослей в Алакольском природном заповеднике, Казахстан. Озеро Алаколь - это уникальный охраняемый природный водоем с градиентом солености, в котором разнообразие водорослей никогАа не изучалось Ао наших исследований. В течение полевых и мабораторных работ 2016-2017 гг. было выявлено 208 вилов воАорослей из пяти таксономических отАелов. Виды диатомовых водорослей сильно преоблаАали в 29 изученных сообществах озера. Статистические методы выявиАи высокую корреляцию межАу интенстивностью развития водорослей и числом чилов в сообществе, а также высокое своеобразие сообществ водорослей на трех изученных сайтах по ССА. Примененный анализ распределения таксономических отделов и индикаторных категорий с помощью статистических карт показал, что виды эвгленовых, которые в основном связаны с поступлением органического вещества, распространяются в озере из поселения Рыбачье. Картографирование биоиндикационных групп выявило вАияние скрытых и впадающих рек Уржар и Жаманты в качестве источников органического загрязнения. Этот вывод можно сАелать на основе статистического картографирования только в дополнение к результатам биоиндикации, поскольку Аанные о переменных среды ограничены. Эта оценка охраняемого озера может служить ориентиром Аля будущих исследований озера Алаколь, а также может помочь в планировании сети станций Аля мониторинга.

КАючевые слова: водоросли, биоиндикация, ССА, экологическое картографирование, органическое загрязнение, озеро А^аколь, Казахстан
The old drainless system of the large lakes in the territory of Kazakhstan included Sasykkol, Uyaly, Zhalanashkol, and other smaller lakes, together with the Alakol Lake are forming the Alakol Lake system (Berezovikov 2006). Lake Alakol is a high-mineralized drainage lake located on the Balkhash-Alakol lowland, which is situated on the border of the Almaty and East Kazakhstan regions, in the eastern part of the Balkhash-Alakol Basin. More than 15 rivers flow into the lake, of which the main are the rivers Urzhar,
Katynsu, Emelkysa, Ygrajty, Zhamanotkel, and Tasty that are permanently dry in the summer period excluding Zhamanty and Urzhar Rivers which are watered near the mouth at the end of July.

The Parliament of Kazakhstan ratified the Convention on Biological Diversity in 1994, thus affirming its intention to preserve the unique richness of nature. A real step towards the implementation of these documents was the creation in 1998 of the Alakol Lake State Reserve. A first 
step of investigation of the new natural reserve monitoring was an identification of the biological diversity. Whereas some aquatic invertebrates were already occasionally studied (Krupa et al. 2010), the algal diversity examination is still at initial stage, thus, up to current research the information about algal species of the Alakol Lake was absent. Our preliminary study during 2016-2017 revealed 208 species and infraspecies of algae that lived the Alakol Lake communities (Jiyenbekov et al. 2018). Only list of species and its taxonomic analysis were represented in cited work. But application of bioindicational methods help us to reveal ecological preferences of revealed species that can help to characterize species habitats in the Alakol Lake.

Some statistical methods can help to reveal relationships between biological data and environmental variables but it's using often is limited when environmental data are not rich that we have in the first stage of the Alakol algae investigation.

It is very important to assess aquatic ecosystem state on the different parts of the protected lake in purpose to reveal the pollution sources and the trophic level of each studied section of the lake, its status in the system of risk assessment (Detenbeck et al. 2000, UNEP/IPCS 2006), or classification status in terms of certain trophic elements (nitrates and phosphates concentration and other chemical variables), and also on biological data expressed in terms of saprobic indices, and other bioindication data (Barinova 2017c).

The aim of the present study was to define a distribution of algal species, taxonomic, and bioindication groups on the lake using modern mapping techniques and comparative floristic for revealing areas and sources of pollution.

\section{MATERIAL AND METHODS \\ Study site description}

Lake Alakol and the adjacent part of the basin of its catchment area is a protected natural area. The lake is a drainless lake, belongs to the ecoregion 624 (Balkash - Alakul) according to the FEOW classification (The Nature Conservancy and World Wildlife Fund (WWF) 2013.) and in the past represented a single water system with Lake Balkhash. It is located at an altitude of $348 \mathrm{~m}$ above sea level on the Balkhash-Alakol lowland, which lies on the border of the Almaty and East Kazakhstan regions, in the eastern part of the Balkhash-Alakol depression (Fig. 1). Only Zhamanty River that input to the Alakol Lake near Koktuma and Urzhar River inputted near Rybachje are more or less permanent and were available for sampling at the end of July and beginning the August of 2016-2017, its water volume is dependent to the season but all other tributaries are dry in the summer period (Berezovikov 2006).

The area of the lake (with islands) is 2,696 square kilometers. The volume of water is 58.56 cubic $\mathrm{km}$. The length of the lake is $104 \mathrm{~km}$, and the width is about $52 \mathrm{~km}$. The average depth is about $22 \mathrm{~m}$ and the maximum depth is $54 \mathrm{~m}$. The length of the coastline is about $348 \mathrm{~km}$. There are few islands in the center of the Alakol: Ulken, Kishkeni Araltobe, Belkuduk, etc. A complex wind regime is observed above the lake. The maximum wind speed over the northern parts of the lake reaches $40-50 \mathrm{~m}$ per second; over the southeastern and central parts is $50-60 \mathrm{~m}$ per second maximum (Berezovikov 2006). The most active winds are in the autumn-winter period when the wave height can be up to $2-2.5 \mathrm{~m}$. The landscape of the catchment basin of the lake represents a not afforested surface with steppe type of vegetation.

The climate of the lake area is sharply continental in semi-arid zone of Eastern Kazakhstan (Berezovikov 2006). The duration of freeze-up is about 2 months (FebruaryMarch). The largest thickness of ice is $0.8 \mathrm{~m}$ (in February). Melting ice is in a period of April-early May. The water temperature reaches $7-15^{\circ} \mathrm{C}$ in late May. The waters of the lake are brackish, the composition is chloride-sodium and chloride-sulfate-sodium, the mineralization varies in the range

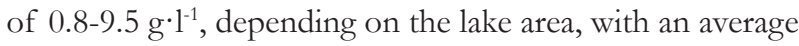
is about 5.9-7.8 $\mathrm{g}^{-1} \mathrm{l}^{-1}$ (Krupa et al. 2010). A high content of fluorine and bromine is registered in the Lake Alakol water (Berezovikov 2006).

\section{Sampling}

The material for this study was obtained from processing 29 samples of microphytobenthos, algae and phytoplankton collected during July-August 2016-2017 summer field trips from three areas of the Alakol Lake itself and two river mouth that was watered in sampling period the Zhamanty and Urzhar rivers (Fig. 1). Phytoplankton samples were collected using Apstein net with a pore diameter of $20 \mu \mathrm{m}$. Microphytobenthos was collected from the stones, plants, and from the lake bottom by scratching of its surfaces. The periphyton was placed in a sampling tube and fixed immediately with $4 \%$ neutral formaldehyde solution. Samples of charophyte algae were collected in the form of whole plants and fixed in a place immediately after sampling mainly by $4 \%$ neutral formaldehyde solution or with $96 \%$ ethanol.

Meteorological conditions of the water, air, and geographic coordinates of sampling points were defined during the collection of algae. The Secchi disk set the water transparency depth, and water $\mathrm{pH}$ was measured with universal indicator paper.

Samples were transported to the laboratory of the Institute of Botany and Phytointroduction, Almaty in the icebox.

\section{Laboratory processing}

Samples were processed in three replicates and viewed under light microscopes MBI-3, Amplival, and Carl Zeiss Axioskop-40 with high-resolution digital camera AxioCam MRc-5 and the AxioVision 4.8 program under the $600 x-1000 x$ magnification. The size of the cells was obtained using an ocular micrometer at the Institute of Botany and Phytointroduction, Almaty. Samples were also processed at the Institute of Evolution, University of Haifa, Israel, under light microscope M4000-D at magnifications 400x $-1000 x$. The preparation of glass slides with diatom algae was made using the peroxide method (Barinova 1988, Barinova 2017a) and investigated in the media of Eliashev and in Canadian balsam.

The abundance of each species in the slides was assessed based on 6-score scale as an abundance of each species cells within the sample volume revealed on the glass slide 


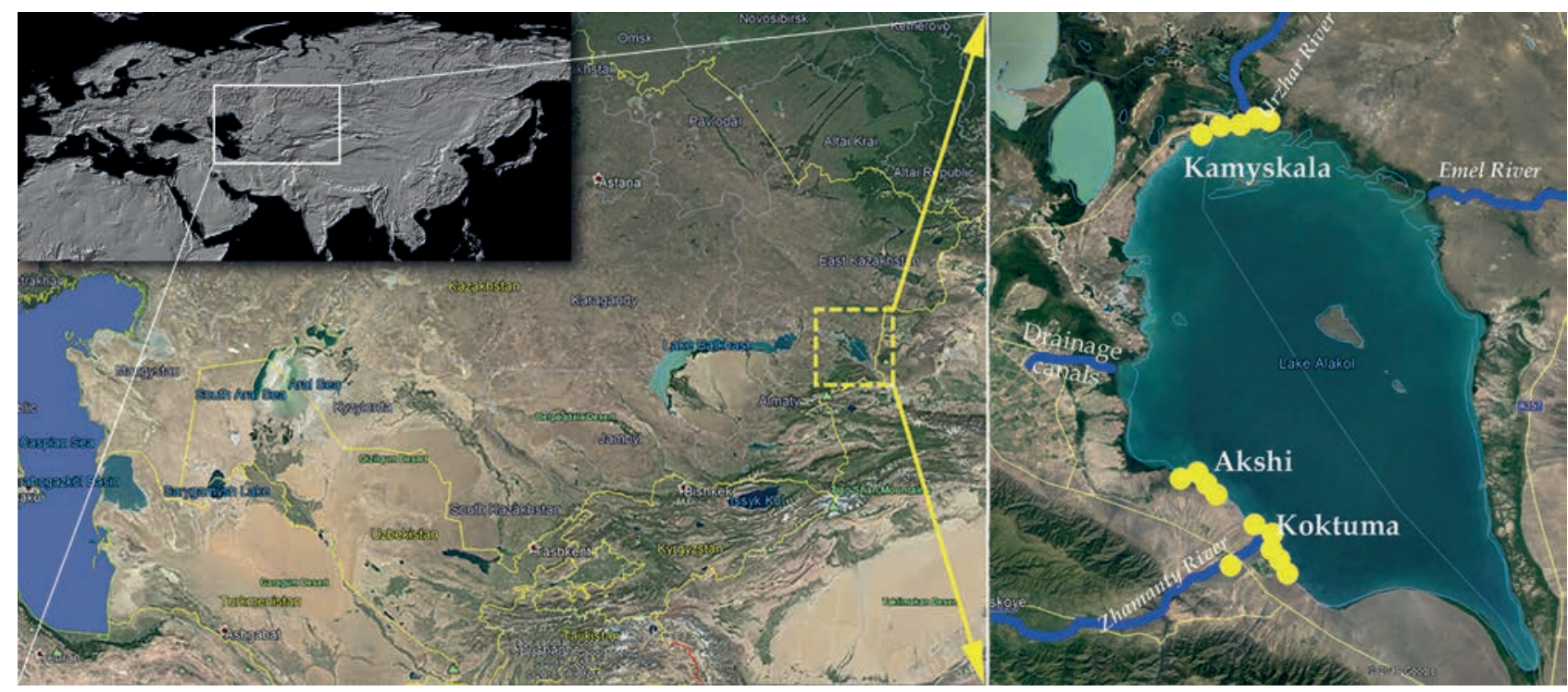

Figure 1 The map of the Alakol Lake with sampling points (yellow) and three sampling areas Kamyskala, Akshi, and Koktuma in 2016-2017

under a microscope (Barinova et al. 2006, Barinova 2017a). The abundance of charophytes was assessed as the percentage of space that they occupied. The defined algal species were photographed under a microscope with digital camera OMAX A35100U or Motic MBI-300.

The species composition was determined using international handbooks. The modern names of taxa were unified with based on the algaebase.org website (Guiry \& Guiry 2018) and organized in accordance with the nomenclature system of Cavalier-Smith (2004).

\section{Statistical treatment}

One of the methods that give an integral representation of the results of bioindication is environmental mapping. However, until recently, the methods used for mapping have been time-consuming, limited, and difficult to interpret (WISE 2012, Firoz et al. 2017). The modern approaches with statistical instruments using for data visualization are developed fast from modeling of industrial data (Montgomery 2008) to implementation statistical instruments to biological data analysis such in the Statistica 12.0 Program. Here program can generate plots that are simply interpreted, better that data in tables and histograms. Up to now, mapped data never included species richness or bioindication results for plotting as surfaces maps avoid the measured by some equipment. The new instrument is able to construct the maps of any biological or environmental data distribution on the surface if the sampling points have GIS coordinates.

Spatial organization of the data includes their collection following the scheme (Barinova 2017b) as recommended in different countries (Higgins et al. 2005) for the basis of the "GAP-analysis" (FitzHugh 2005) that includes optimization of the work with using mapping in GIS. So, visualization with statistical methods can improve the bioindication results presentation and comparison. In the wafer-map are visualize the data rendered as a contour $3 \mathrm{D}$ plot using the Wafer fit method in Statistica 12.0 program. The wafer fit method displays surface data in a direct format when the multiple values are averaged so that there is just one value for every similar pair of data. The resulting plot can be displayed either in 3D form as a surface or in 3D form as a contour plot, and we were constructing it for the lake the last variant.

Ecological preferences of the species were assessed based on our database (Barinova et al. 2006). Ecological maps were constructed in Statistica 12.0 program. GRAPHS and Statistica 12.0 programs were used for the construction of the dendrogram and dendrite for comparative floristics (Novakovsky 2004).

\section{RESULTS AND DISCUSSION}

The temperature of water in the sampling points during 2016-2017 summer field trips was about $22-23^{\circ} \mathrm{C}$, and the $\mathrm{pH}$ of the water was about 7.5. A total of 208 species and infraspecies of algae and cyanobacteria from five taxonomic divisions were identified in 29 samples of phytoplankton and microphytobenthos of the Alakol Lake (Jiyenbekov et al. 2018). We choose the value of the indicator for the revealed species from our database (Barinova et al. 2006) and found out that all revealed taxa have indicators of significance. Ecological parameters of indicator species over three areas of sampling stations of the lake are represented in Table 1.

Correlation matrix (Table 2) demonstrated a high positive correlation $(0.99, \mathrm{p}<0.05)$ between species richness and algal abundance, calculated as the sum of scores. Water temperature also stimulated algal abundance but Index saprobity $\mathrm{S}$, which reflect organic pollution in the lake water has a low negative correlation with temperature and algal abundance. The pairwise forward analysis for Abundance as a dependent parameter and water temperature, Index saprobity $\mathrm{S}$, and species richness as independent variables also revealed species richness as the parameter which influenced algal abundance $\left(\mathrm{R}^{2}=0.99, \mathrm{p}=0.08\right)$. So, can be concluded that algae prefer grow in multispecific communities in the Alakol Lake. 
Table 1. Distribution of species richness in taxonomic divisions and average number of indicator taxa over three sampling areas of the Alakol Lake in 2016-2017.

\begin{tabular}{|c|c|c|c|}
\hline Variable & Kamyskala & Akshi & Koktuma \\
\hline $\begin{array}{l}\text { Total no. of Species } \\
\text { Index saprobity S }\end{array}$ & $\begin{array}{c}79 \\
0.56-2.86\end{array}$ & $\begin{array}{c}19 \\
1.31-2.47\end{array}$ & $\begin{array}{c}114 \\
1.08-3.50\end{array}$ \\
\hline $\begin{array}{l}\text { Taxonomic division } \\
\text { Bacillariophyta } \\
\text { Charophyta } \\
\text { Chlorophyta } \\
\text { Cyanobacteria } \\
\text { Euglenozoa }\end{array}$ & $\begin{array}{c}52 \\
4 \\
5 \\
13 \\
5\end{array}$ & $\begin{array}{c}19 \\
0 \\
0 \\
0 \\
0\end{array}$ & $\begin{array}{l}79 \\
16 \\
10 \\
8 \\
1\end{array}$ \\
\hline $\begin{array}{l}\text { Habitat indicators } \\
\text { S } \\
\text { B } \\
\text { P-B } \\
\text { P }\end{array}$ & $\begin{array}{c}3 \\
44 \\
28 \\
4\end{array}$ & $\begin{array}{c}1 \\
14 \\
4 \\
0\end{array}$ & $\begin{array}{c}1 \\
70 \\
29 \\
8\end{array}$ \\
\hline $\begin{array}{l}\text { Temperature indicat } \\
\text { cool } \\
\text { temp } \\
\text { eterm } \\
\text { warm }\end{array}$ & tors $\begin{array}{l}3 \\
7 \\
0 \\
0 \\
2\end{array}$ & $\begin{array}{l}0 \\
6 \\
0 \\
0\end{array}$ & $\begin{array}{c}1 \\
18 \\
2 \\
4\end{array}$ \\
\hline $\begin{array}{l}\text { Oxygenation indicat } \\
\text { aer } \\
\text { str } \\
\text { st-str } \\
\text { st }\end{array}$ & tors $\begin{array}{c} \\
3 \\
8 \\
31 \\
6\end{array}$ & $\begin{array}{l}0 \\
7 \\
4 \\
2\end{array}$ & $\begin{array}{c}3 \\
8 \\
38 \\
14\end{array}$ \\
\hline $\begin{array}{l}\text { Water } \mathrm{pH} \text { indicators } \\
\text { acf } \\
\text { ind } \\
\text { alf } \\
\text { alb }\end{array}$ & $\begin{array}{c}2 \\
27 \\
20 \\
1\end{array}$ & $\begin{array}{c}2 \\
4 \\
10 \\
0\end{array}$ & $\begin{array}{c}6 \\
37 \\
38 \\
4\end{array}$ \\
\hline $\begin{array}{l}\text { Salinity indicators } \\
\text { hb } \\
\text { i } \\
\text { hl } \\
\mathrm{mh}\end{array}$ & $\begin{array}{c}5 \\
36 \\
9 \\
9\end{array}$ & $\begin{array}{c}1 \\
14 \\
1 \\
1\end{array}$ & $\begin{array}{c}5 \\
70 \\
9 \\
6\end{array}$ \\
\hline $\begin{array}{l}\text { Watanabe saprobity } \\
\text { es } \\
\text { sp } \\
\text { sx }\end{array}$ & $\begin{array}{c}\text { indicators } \\
12 \\
5 \\
8\end{array}$ & $\begin{array}{l}7 \\
1 \\
4\end{array}$ & $\begin{array}{c}31 \\
3 \\
15\end{array}$ \\
\hline $\begin{array}{l}\text { Class of water qualit } \\
\text { Class } 1 \\
\text { Class } 2 \\
\text { Class } 3 \\
\text { Class } 4 \\
\text { Class } 5\end{array}$ & $\begin{array}{c}4 \\
28 \\
26 \\
9 \\
1\end{array}$ & $\begin{array}{l}3 \\
6 \\
7 \\
1 \\
0\end{array}$ & $\begin{array}{c}9 \\
41 \\
34 \\
8 \\
0\end{array}$ \\
\hline $\begin{array}{l}\text { Trophic state indica } \\
\text { ot } \\
\text { o-m } \\
\text { m } \\
\text { me } \\
\text { e } \\
\text { o-e }\end{array}$ & $\begin{array}{cc}\text { tors } \\
12 \\
4 \\
5 \\
11 \\
9 \\
3\end{array}$ & $\begin{array}{l}2 \\
5 \\
3 \\
1 \\
3 \\
1\end{array}$ & $\begin{array}{l}5 \\
14 \\
14 \\
15 \\
12 \\
5\end{array}$ \\
\hline $\begin{array}{l}\text { Nutrition type indic } \\
\text { ats } \\
\text { ate } \\
\text { hne } \\
\text { hce }\end{array}$ & $\begin{array}{c}\text { ators } \\
8 \\
17 \\
0 \\
0\end{array}$ & $\begin{array}{l}9 \\
0 \\
2 \\
0\end{array}$ & $\begin{array}{l}14 \\
22 \\
2 \\
1\end{array}$ \\
\hline
\end{tabular}

Note: Abbreviation of the ecological groups of indicators (Barinova et al. 2006): Habitat preferences: $\mathrm{P}$ - planktonic, P-B - planktonic-benthic, $\mathrm{B}-$ benthic, wide range, need some substrate; $\mathrm{S}$ - soil Wic-benthic, $\mathrm{B}$ - benthic, wide range, need some substrate; $\mathrm{S}$ - soll. Water temperature preferences: warm - warm-water inhabitants;
cool - cool-water inhabitants; temp - temperate water temperacool - cool-water inhabitants; temp - temperate water tempera-
ture inhabitants or indifferent; eterm - eurythermic. Oxygenation indicators: st - standing water, str - streaming water, st-str - low streaming water, aer - aerophiles. Salinity: hb - oligohalobes-halophobes, $\mathrm{i}$ - oligohalobes-indifferents, $\mathrm{mh}$ - mesohalobes, $\mathrm{h}$ - halophiles. Acidity $(\mathrm{pH})$ degree indicators: alb - alkalibiontes alf - alkaliphiles, ind - indifferents; acf - acidophiles. Watanabe indicators of organic pollution: sx - saproxene; es - eurysaprobe; sp - saprophile. Nutrition type indicators (Van Dam et al. 1994): ats - nitrogen-autotrophic taxa, tolerating very small concent rations of organically bound nitrogen; ate - nitrogen-autotrophic taxa, tolerating elevated concentrations of organically bound nitrogen; hne - facultatively nitrogen-heterotrophic taxa, needing periogically elevated concentrations of oroanically bound nitrogen; hce dically elevated concentrations of organically bound nitrogen; hce - obligately nitrogen-heterotrophic taxa, needing continuously elevated concentrations of organically bound nitrogen. Trophic state indicators (Van Dam et al. 1994$)$ : ot - oligotraphentic; o-m - oligo-
mesotraphentic; $\mathrm{m}$ - mesotraphentic; me - meso-eutraphentic; e mesotraphentic; $\mathrm{m}$ - mesotraphentic; me - meso-eutraphentic;
eutraphentic; o-e - oligo- to eutraphentic (hypereutraphentic).
Table 2. Correlation matrix between biological and environmental variables of the Alakol Lake in 2016-2017. Negative correlations are marked by bold.

\begin{tabular}{l|llll} 
& Temp. & Abund. & Index S & No of Sp. \\
\hline Temperature & 1.000000 & & & \\
Abundance & 0.403325 & 1.000000 & & \\
Index S & $\mathbf{- 0 . 0 4 9 5 1 2}$ & $\mathbf{- 0 . 0 1 0 3 0 7}$ & 1.000000 & \\
No of Species & 0.396935 & 0.995557 & 0.013872 & 1.000000
\end{tabular}

The surface plots in Fig. 2 demonstrated increasing of species richness (Fig 2a), algal abundance (Fig 2b), and Cyanobacteria species number in communities (Fig 2c) with increasing of water temperature and Index saprobity S. Only Euglenophyta species richness preferred organically enriched waters of low temperature (Fig 2d).

The CCA analysis of relationships between environmental variables and abundant species data show (Fig. 3) joint influence of species richness and algal abundance together with water temperature on the communities of the Koktuma site. In the same time, algae in Kamyskala site more influenced by organic pollution and preferred temperate temperature waters were formed of low species-rich and low abundant communities. It is known that the Urzhar river delta is the most polluted in the region because the Rybachje village is located near the river mouth (Rivers of the East Kazakhstan region) and polluted the river and northern part of the lake aquatory. Akshi site algae preferred moderate temperature low organically polluted water in which formed low abundant communities with low species number.

Therefore, we decide to clarify species and environment relationships in Alakol Lake with the help of bioindication (Table 1) and statistical methods. In this way, each revealed species was characterized by its ecological preferences over ten ecological variables (Barinova et al. 2006, Barinova \& Fahima 2017).

Ecological maps for species richness in each taxonomic division and for each of the ecological indicators group were constructed using Statistica 12.0 program based on our data for each of 29 sampling points on the Alakol Lake surface. Our preliminary experience of the statistical generation of maps demonstrated the simplicity of data mining and the availability of the method for all received variables (Barinova 2017b). The mapping gives us a base for an ecological assessment of the Balkhash Lake in Kazakhstan (Barinova et al. 2017a, Krupa et al. 2018), polluted Shardara reservoir (Barinova \& Krupa 2016, 2017), as well as diverse examples for the lakes and reservoirs in Eurasia (Barinova et al. 2017b).

Distribution of species richness of five taxonomic divisions in the Alakol Lake community is shown on the Fig. 4a-e. The diversity of diatoms, charophytes and chlorophyte algae are high in the southernmost area near Koktuma, whereas cyanobacteria and euglenoids are more diverse in the northern part of the lake near Kamyskala area. Total species richness is the same as the distribution of diatoms (Fig. 4f) because this taxonomic group of algae was prevailing in the total species list. Structure indicator, the Shannon index, has similar distribution (Fig. 4g) with the highest value in the southern part; however, some com- 


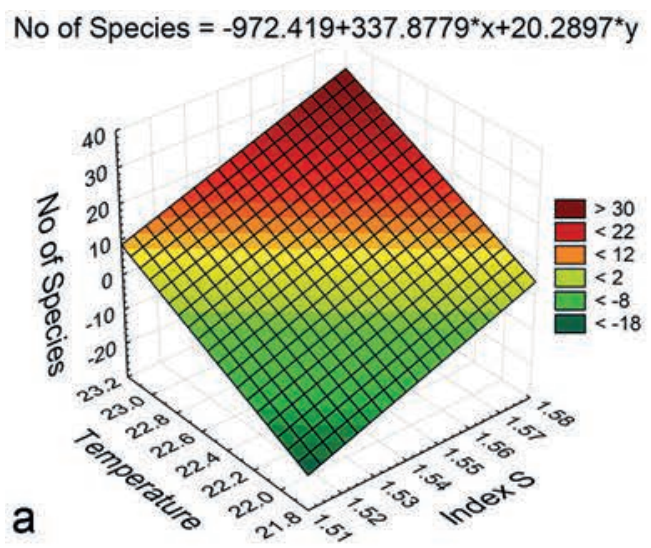

Abundance $=-2273.5081+47.1248^{\star} x+793.3505^{\star} y$
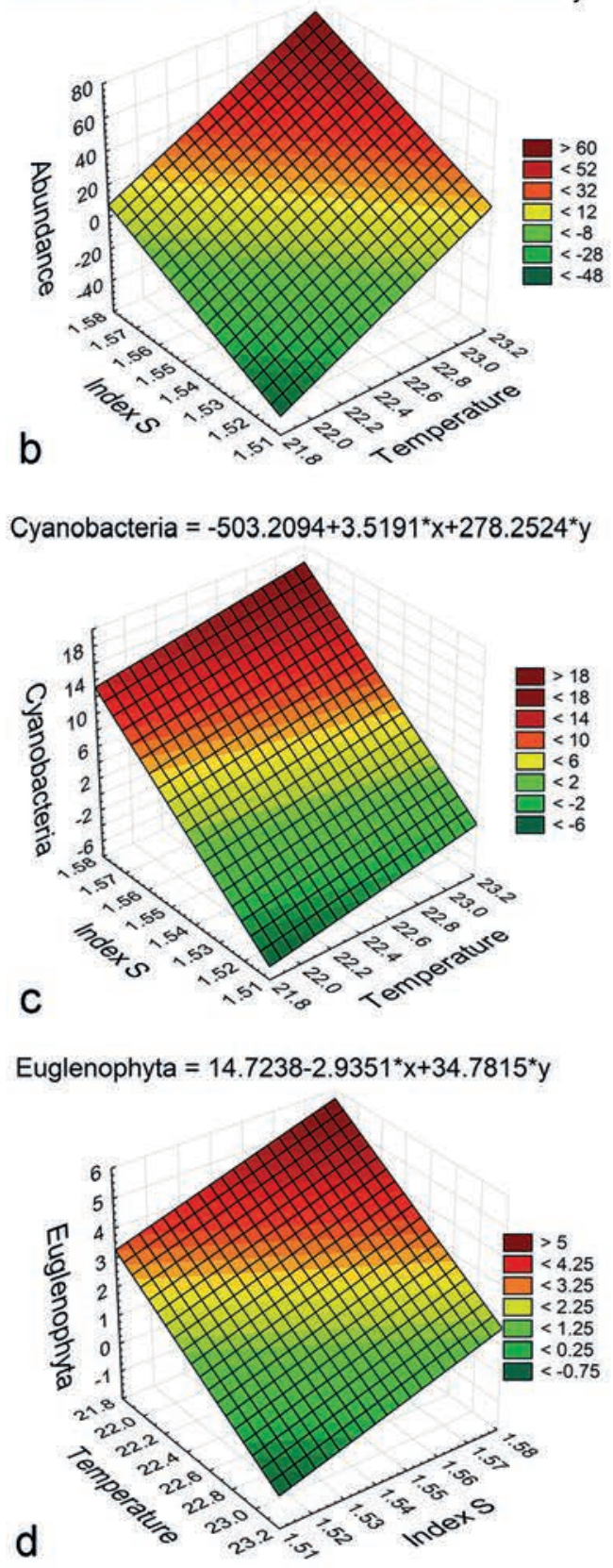

Figure $23 \mathrm{D}$ surface plots of relationships species richness (a), abundance (b), Cyanobacteria species richness (c), Euglenophyta species richness (d), water temperature and Index saprobity $S$ as evidence of organic pollution in the Alakol Lake in 2016-2017

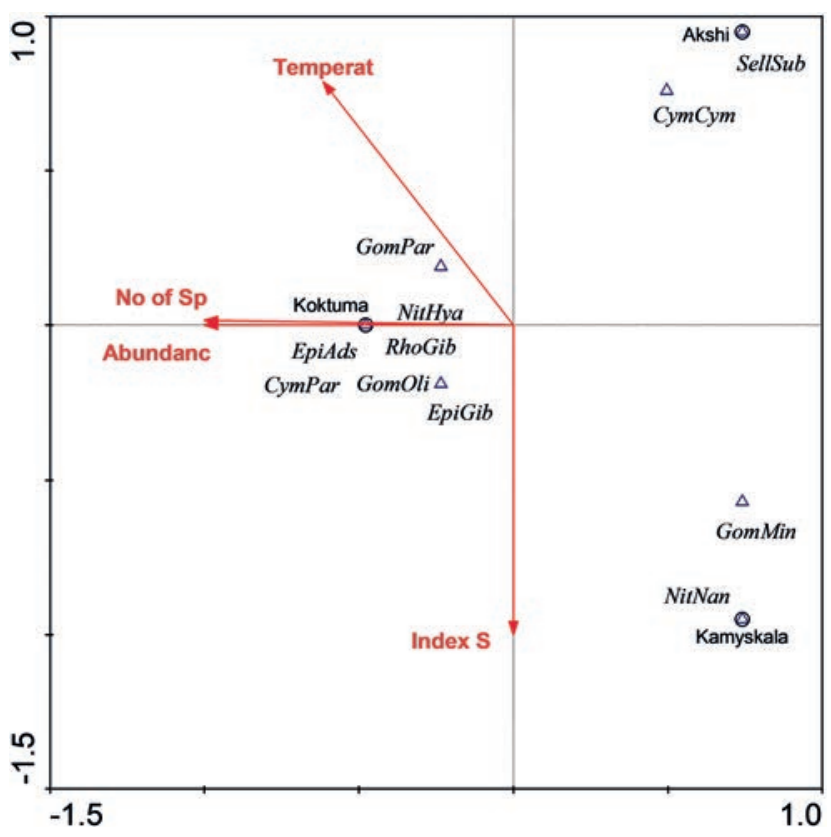

Figure 3 Canonical correspondence analysis (CCA) of abundant species and average environmental variables in three studied sites relationships. Abbreviations: ChaAsp - Chara aspera C.L. Willdenow; CymCym - Cymbella cymbiformis C. Agardh; CymPar - C. parva (W. Smith) Kirchner; EpiAds - Epithemia adnata var. saxonica (Kützing) R.M. Patrick; EpiGib - E. gibba (Ehrenberg) Kützing; GomMin - Gomphonema minutum (C. Agardh) C. Agardh; GomOli G. olivaceum (Hornemann) Brébisson; GomPar - G. parvulum (Kützing) Kützing; NitHya - Nitella hyalina (De Candolle) C. Agardh; NitNan - Nitascbia nana Grunow; RhoGib - Rhopalodia gibba (Ehrenberg) Otto Müller; SellSub - Sellaphora submuralis (Hustedt) C.E. Wetzel, L. Ector, B. Van de Vijver, Compère \& D.G. Mann

munities with euglenoids in the northern area were also stable with high Shannon index. These distributions are similar to those in the Balkhash Lake (Barinova et al. 2017a, Krupa et al. 2018), where species richness is specific in the gradients of different environmental factors and is higher and diverse near the mouth of the influent river.

Fig. $4 \mathrm{~h}-\mathrm{k}$ demonstrated more or less concentration of all types of substrate preferences indicators in the southern part of the lake that correlated with the highest species richness. Only indicators of well-oxygenated waters are sufficiently presented on the map (Fig. 4h) near the Kamyskala area.

Measurements of water temperature of the lake surface during summer trips showed its increase from north to south (Fig. 4l), which is consistent with the distribution of the bioindicators. Thus, indicators of cool water (Fig. $4 \mathrm{~m}$ ) are marked in the Zhamanty River estuary as well as, mostly, near the Kamyskala area where water flows from the river Urzhar during spring rainy period. Indicators of moderate temperature water are distributed over the lake with increasing of its diversity near Akshi area (Fig. 4n). We revealed only a few indicators of warm waters. They were present in communities of the Zhamanty river estuary (Fig. 4o). Previous experience with the construction of the maps for the cooling pond of the Khmelnitsky Nuclear Power Plant, Ukraine (Barinova et al. 2017b) demonstrated different distribution due to its artificial nature with a large gradient of water temperatures. Thus, the distribution of temperature indicators in the Alakol Lake reflected not only 

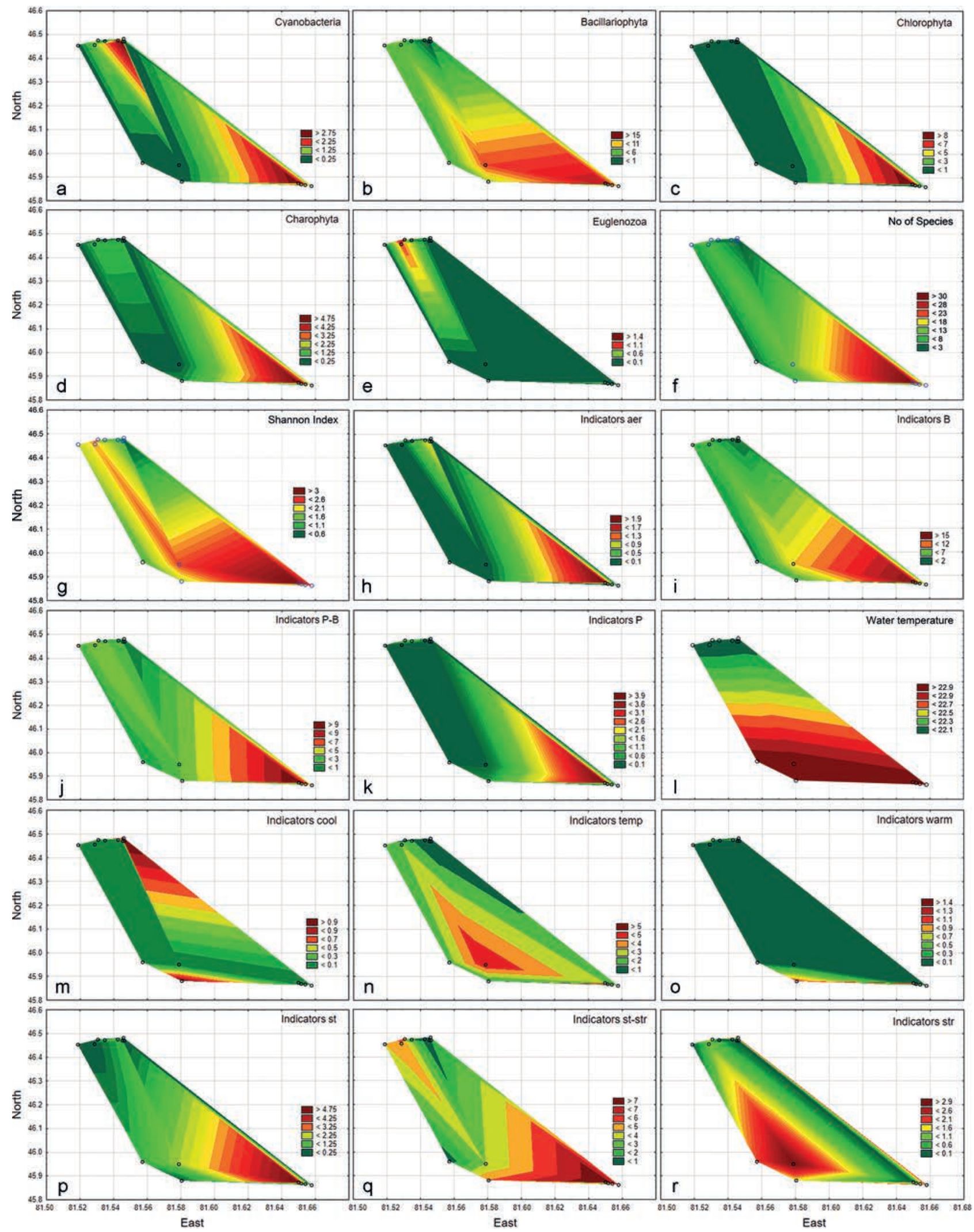

Figure 4 The maps of various algae diversity and habitat indicators the Alakol Lake surface in 2016-2017. In species richness of taxonomic divisions distribution: Cyanobacteria (a), Bacillariophyta (b), Chlorophyta (c), Charophyta (d) and Euglenozoa (e); in alpha-diversity of algae communities (f) and Shannon Index (g); habitat preferences indicators distribution: aerophiles (h), benthic (i), plankto-benthic (j), planktonic $(\mathrm{k})$; water temperature (l) and temperature indicators: cool-water indicators $(\mathrm{m})$, temperate-water indicators $(\mathrm{n})$, warm-waters indicators $(\mathrm{o})$; mobility of water and its oxygen saturation: standing-waters low oxygenated (p), standing-streaming waters medium oxygenated (q), streaming-waters well-oxygenated (r) 

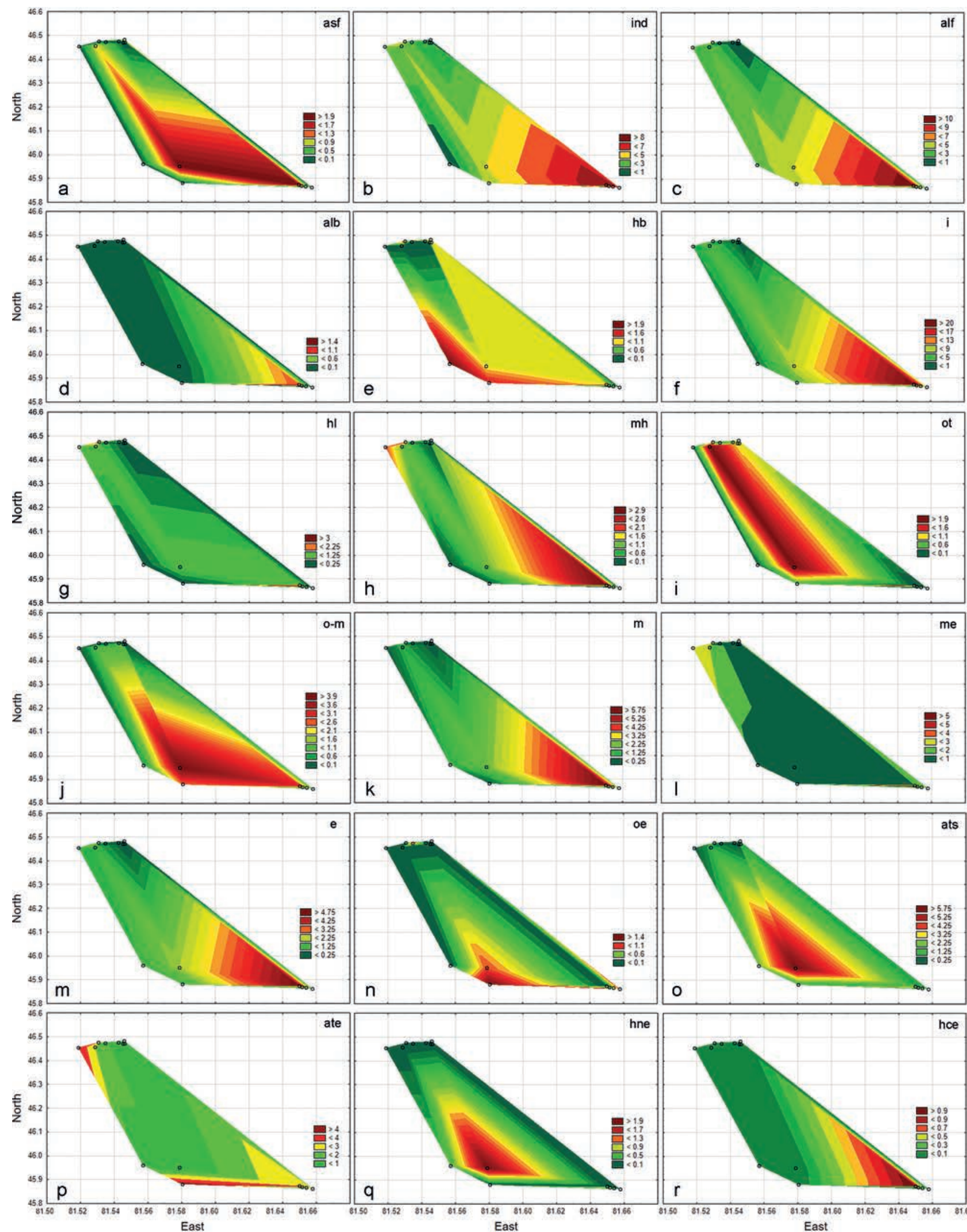

Figure 5 The maps of various habitat indicators the Alakol Lake surface in 2016-2017. In water pH indicators: acidophiles (a), pH-indifferents (b), alkaliphiles (c), alkalibiontes (d); water salinity indicators: halophobes (e), indifferents (f), halophiles (g), mesohalobes (h); trophic state indicators: ot - oligotraphentic (i), o-m - oligo-mesotraphentic (j), $\mathrm{m}$ - mesotraphentic ( $\mathrm{k}$ ), me - meso-eutraphentic (l), e - eutraphentic (m), o-e - oligo- to eutraphentic (hypereutraphentic) (n); nutrition type indicators: ats - nitrogen-autotrophic taxa, tolerating very small concentrations of organically bound nitrogen $(\mathrm{o})$, ate - nitrogen-autotrophic taxa, tolerating elevated concentrations of organically bound nitrogen (p), hne - facultatively nitrogen-heterotrophic taxa, needing periodically elevated concentrations of organically bound nitrogen (q), hce - obligately nitrogen-heterotrophic taxa, needing continuously elevated concentrations of organically bound nitrogen ( $\mathrm{r}$ ) 


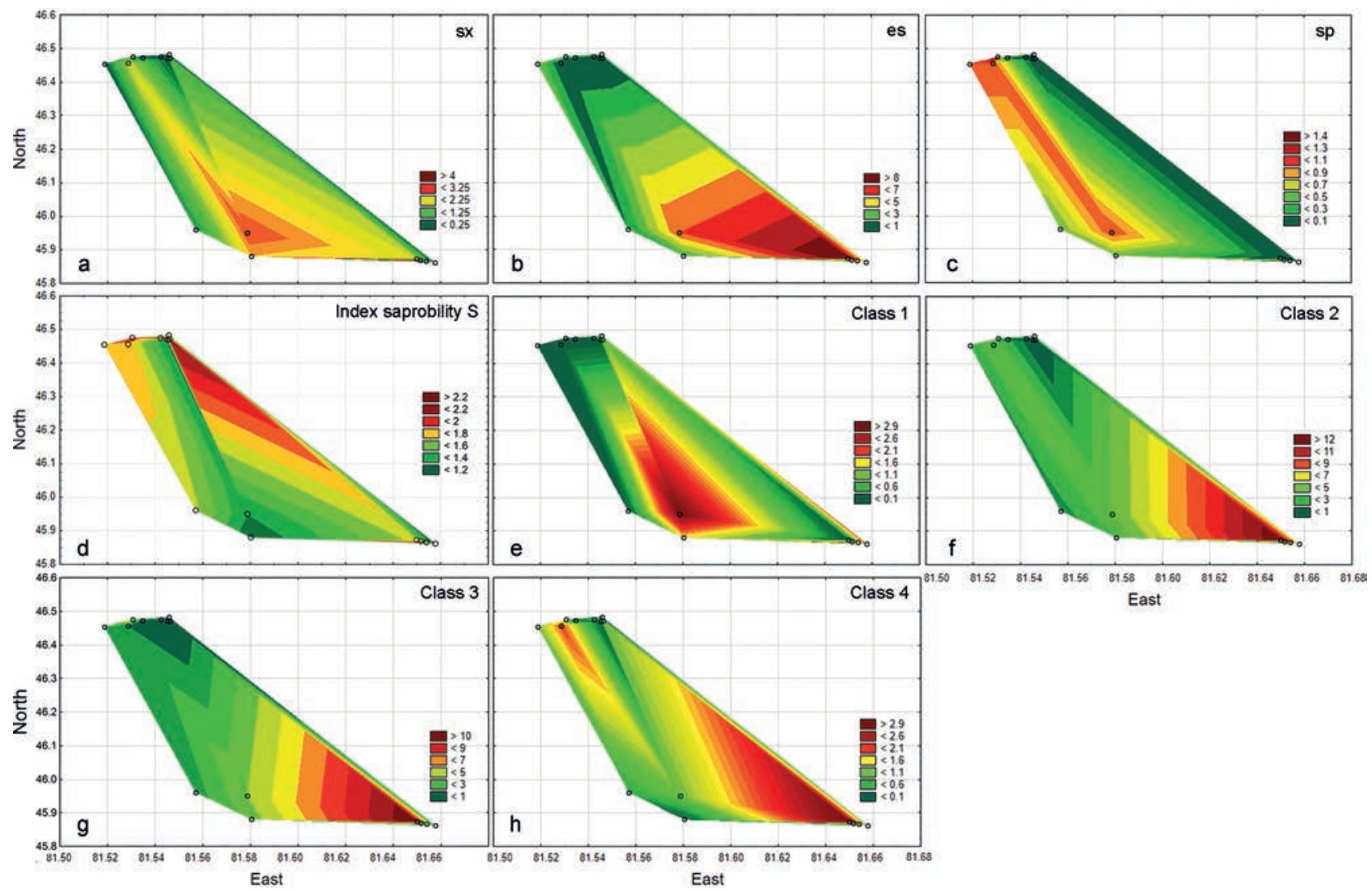

Figure 6 The maps of various habitat indicators the Alakol Lake surface in 2016-2017. Organic pollution indicators according Watanabe: saproxenes (a), eurysaprobes (b), saprophiles (c), Index Saprobity S (d); Class of Water Quality indicators: Class 1 (e), Class 2 (f), Class 3 (g), Class $4(\mathrm{~h})$

natural water body properties, but also help us to reveal the underground flow of the rivers that are almost dry during the sampling period.

Maps on the Fig. $4 \mathrm{a}-\mathrm{c}$ help us to conclude that lake has more standing water near Koktuma area (Fig. 4p), whereas indicators of streaming waters are diverse near Akshi area (Fig. 4q). Mobility of water in the lake is indicated not only in the southern part near Koktuma but also in the northern part of the lake near hidden Zhamanty River estuary (Fig. 4r). This distribution is similar to the maps of the Shardara reservoir indicators, in which concentration of indicators of moving and well-oxygenated waters can be seen near the inflowing rivers (Barinova \& Krupa 2017).

The indicator species of water $\mathrm{pH}$ shown sufficient differences of its group's distribution on the lake surface although the water $\mathrm{pH}$ in the lake has small fluctuation amplitude of this variable measured during the field trips. Acidity influence can be related to the inflow of the Urzhar River into the lake, but mostly revealed in the southern part of the lake (Fig. 5a). Indicators of neutral and low alkaline waters show a similar distribution and are concentrated near Koktuma area (Fig. 5b-c). The high-alkaline water indicators, alkalibiontes are found only near Koktuma area (Fig. 5d). Similar distribution with the correlation of the acidic water indicators and macrophytes in the water body near the river estuary can be seen in ecological assessment using statistical mapping of the Shardara reservoir as well as alkalibiontes near nude coast of the lake (Barinova \& Krupa
2017). Revealed influence of the inflowing of hidden rivers on the lake water is similar to such in the Sasyk reservoir in Ukraine according to the result of statistical mapping (Barinova et al. 2016, Bilous et al. 2016).

Four ecological groups of salinity tolerance indicators (Fig. $5 \mathrm{e}-\mathrm{h}$ ) show wide amplitude from halophobes to salinity tolerant mesohalobes. Although halophobes are mostly present in communities of the Akshi area (Fig. 5e), salt concentration indifferent indicators are correlated with total species richness (Fig. 5f), whereas halophiles have flattened distribution over the surface of the lake (Fig. $5 \mathrm{~g})$. Only mesohalobes, the indicators of saline waters, demonstrated the influence of salinity from two different sources (Fig. 5h), the Koktuma area and the Rybachje settlement in the Kamyskala area. Our mapping of the Balkhash Lake and Shardara reservoir shows different results with the correlation of water salinity mostly correlated with the rivers input (Barinova \& Krupa 2017, Barinova et al. 2017a, Krupa et al. 2018).

It is important to know the trophic state of the protected lake because it can serve as a reference for future monitoring of the lake ecosystem. In our case, when we cannot assess trophic state with chemical methods in the initial stage of investigation of the Alakol Lake ecosystem the bioindication methods are very helpful. Thus, the ecological maps of the trophic state of the lake show (Fig. 5i-n) that the middle part of the lake close to Kamyskala area can be oligotrophic in prognosis (Fig. 11i) whereas 


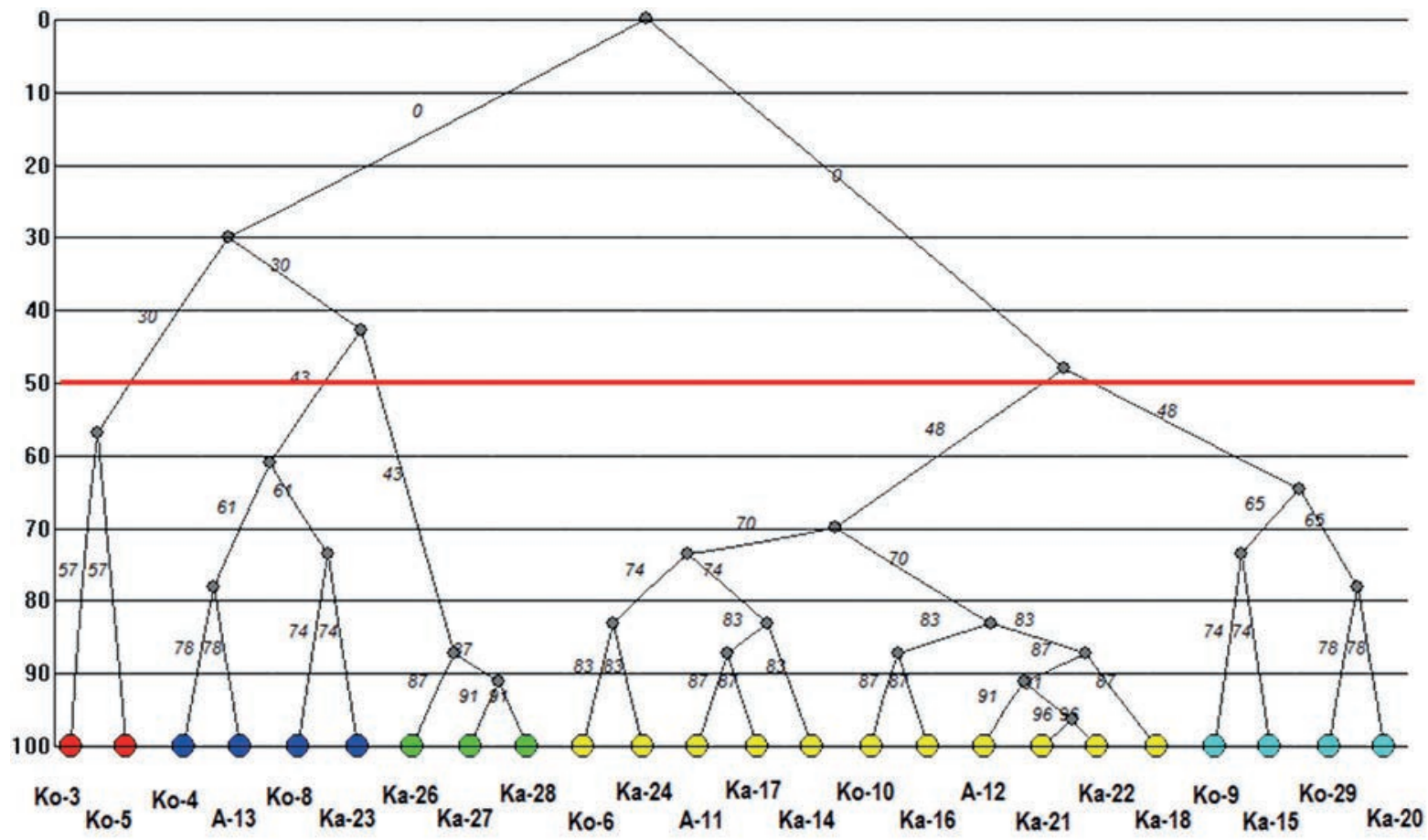

Figure 7 Dendrogram of species richness similarity for the Alakol Lake algal communities in 2016-2017. Clusters are marked by different colors

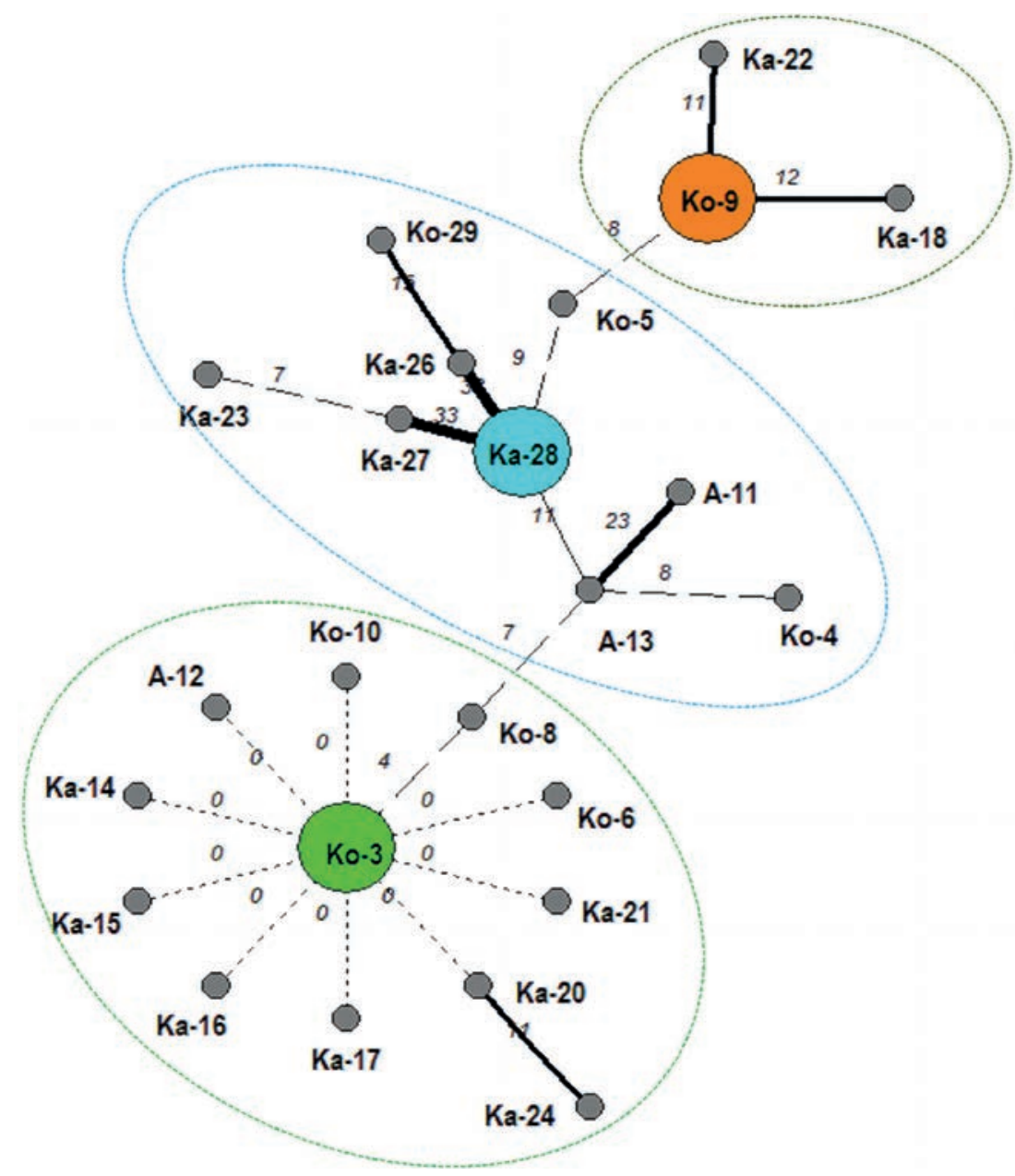

Figure 8 An inclusion-crossing dendrite for the Alakol Lake algal communities in 2016-2017. Floristic cores are marked by different colors. The thickness of connection lines is directly proportional to the value of the relatedness
Koktuma area is mesotrophic (Fig. $5 j-k)$. Eutrophication started from the Rybachje settlement in the Kamyskala area (Fig. 5l) and increased its potential in the Koktuma area (Fig. $5 \mathrm{~m}$ ) with the maximal concentration of the oligo- to eutrophic indicators group (o-e) in the Zhamanty River estuary (Fig. 5n). We can see the similar distribution of the trophic state indicators in the Balkhash Lake, in which source of pollution was allocated near the fishing industry area (Barinova et al. 2017a, 2018, Krupa et al. 2018), similarly to the Rybachje settlement of the Alakol Lake.

Algae, as photosynthetic primary producers, are responsible for self-purification process in the lake ecosystem. Most of the algal species have nutrition with photosynthesis only, but some species have a possibility to uptake dissolved organic matters from the water and demonstrate a heterotrophic way of nutrition. The facultative heterotrophs choose photosynthetic way under normal environmental conditions, however, stick to heterotrophy when some chemicals affect them. Mapping the distribution of nutrition type indicators on the lake surface demonstrate areas, in which normal photosynthetic nutrition way was affected. The 
distribution of autotrophy indicator groups with a concentration of this type of species near Akshi area and some representation in other areas of the lake is shown of the Fig. $5 \mathrm{o}, \mathrm{p}$. Indicators of periodical heterotrophy are also presented mostly near the Akshi area (Fig. 5q). However, indicators of prevailing heterotrophic way of nutrition are concentrated near the southernmost area of Koktuma (Fig. 5r). This distribution is similar to it in the Shardara reservoir, where eutrophication source is related to the inflowing rivers and drainage canals (Barinova \& Krupa 2017).

Therefore, organic pollution plays an important role in the process of water quality formation. The maps of the distribution of diatom saprobity indicators show sources of influences on the lake ecosystem. Whereas indicators of clean water are presented mostly near Akshi area (Fig. 6a), the group of middle organic pollution indicators is concentrated near Koktuma area (Fig. 6b). It is important that the map of high organic pollution indicators distribution demonstrates input of pollution from the Rybachje settlement in Kamyskala area, which influence can be seen even up to the Akshi area near the lake coast (Fig. 6c). Assessment of organic pollution was based on the species-specific index saprobity $\mathrm{S}$ that is related to the Water Quality Class. Our calculation of index $\mathrm{S}$ take to account not only diatoms but also species from total taxa list and show highest $\mathrm{S}$ values near Kamyskala area as well as near Rybachje settlement (Fig. 6d) similarly to the situation in the Shardara reservoir (Barinova \& Krupa 2017).

The distribution of indicators of water quality classes shows obvious presence of water indicators Class 1 near Akshi area (Fig. 6e), indicators of Class 2 and 3 near Koktuma area (Fig. $6 \mathrm{f}-\mathrm{g}$ ), and polluted water indicators of Class 4 near Koktuma area as well as near Rybachje settlement (Fig. 6h), similarly to the Shardara reservoir (Barinova \& Krupa 2017).

We calculated the similarity of the algal species lists in studied samples by Sorensen-Chekanovsky indices and constructed the tree of similarity based on the Euclidian distance (Fig. 7) for the Alakol Lake communities using GRAPHS program. The dendrogram shows five different clusters separated in the $50 \%$ level of similarity. Cluster 1 included two sites in Koktuma area with highest species richness (red circles). Cluster 2 combines four sites lists that have also high diversity and related to different areas, such as Koktuma, Akshi, and Kamyskala (dark blue circles), and included also community with macrophyte alga Chara aspera C.L. Willdenow in the Koktuma area. Clusters 1 and 2 represent well-developed communities with 10-29 species, which indicate alkaline well-oxygen saturated water with medium salinity and Class of water quality 2-3. Cluster 3 combines three communities from Kamyskala area with a strong predominance of macrophyte alga Chara vulgaris $\mathrm{L}$. (green circles). The highlighted with yellow cluster 4 is the largest and includes 11 communities, which have low species number and distributed over all three studied areas. The last one cluster 5 included four communities from Koktuma and Kamyskala areas that have the same preferences as clusters 1 and 2, but with low species richness (blue circles).

The dendrite of inclusion-crossing for the Alakol Lake communities (Fig. 8) demonstrated three floristic cores of algal diversity. The first core includes Koktuma and $\mathrm{Ka}$ myskala communities (orange) with species, mostly diatoms that are true photosynthetic and indicate well-saturated by oxygen, low alkaline, oligo- to mesotrophic water. Second core (blue) comprised of the communities of macrophyte alga Chara vulgaris L. and diverse diatoms and euglenoids, which characterize low-alkaline, saturated by oxygen, oligotrophic waters with developed phytobenthos from all three studied areas. Green-marked core included communities with low species number, which preferred low alkaline clear waters. Moreover, only two communities in the Kamyskala area have similarity, whereas all the others are clearly distinct from each other (Fig. 8).

\section{CONCLUSION}

We studied algal diversity in the Alakol Lake Natural Reserve for the first time and found that there is no information about it in the recent publications. One of the important things for new natural reserve studies is the registration of the species diversity. As a result of our first step study in this purpose, we revealed 208 algal species that are coming from our sampling trips during 2016-2017. The analysis of the distribution of algal species and their ecological preferences based on divisional diversity and bioindication results was done for the first time. Ecological mapping of taxonomic species and bioindication groups distribution as a new and informative approach was implemented for assessment of the Alakol Lake Natural Reserve ecosystem. This statistical method is simple and informative and has been used previously for mapping of environmental and biological variables of the Kazakhstan lakes and reservoirs. Our mapping results demonstrated high effectivity in revealing of pollution sources as well as critical points for different variables of the Alakol protected the lake. Thus, despite the prevalence of diatom species, we, nevertheless, were able to reveal the spatial distribution of species from other taxonomic division and conclude that euglenoids, which mostly correlated with organic matter input, are distributed from the Rybachje settlement across the lake near its eastern coast. Mapping of bioindication groups helped us to reveal an influence of hidden and inflowing rivers no the Alakol Lake ecosystem. Most of them were indicated as sources of organic pollution, such as the Rybachje settlement, and hidden during summer period the Urzhar River, as well as Zhamanty River near Koktuma area, which was similarly revealed by ecological mapping of the Balkhash Lake, Shardara reservoir in Kazakhstan, Sasyk reservoir in Ukraine and was in contrary of distribution in the NPP Khmelnitsky artificial cooling pond in Ukraine. This conclusion can be made using easy operated and available statistical program even when we were limited in terms of the environment variables and used only bioindication results. Comparative floristics highlights also high individuality of communities in the Alakol Lake with especial dominance of charophyte macroalgae and helps to characterize the lake as oligo- to mesotrophic, low alkaline, with insignificant pollution, and low saline that means that high salt saturation of the lake water is caused mostly by sulfates than chlorides.

Therefore, this assessment of the Alakol protected lake can serve as a reference for future investigations, which will 
receive new data about algal communities and environmental variables of the lake, as well as will to assist to plan the net of monitoring stations.

\section{ACKNOWLEDGEMENTS}

The work was carried out under the project № 1846/ГФ4 Г.2015-Г2016 for Committee of Science, Ministry of Education and Science, Republic of Kazakhstan "Development of the methods for controlling the ecological state of water bodies in Kazakhstan" as well as partly supported by the Israeli Ministry of Aliyah and Integration.

\section{LITERAT URE CITED}

Babkin, A. 2019. PaleoKarakhstan.info. Available at http:// paleokazakhstan.info/bal_al.php. Last accessed 09.04.2019

Barinova, S. 2017a. How to align and unify the cell counting of organisms for bioindication. International Journal of Environmental Sciences and Natural Resources 2(2):555-585.

Barinova, S. 2017b. Ecological mapping in application to aquatic ecosystems bioindication: problems and methods. International Journal of Environmental Sciences and Natural Resources 3(2):1-7.

Barinova, S. 2017c. On the classification of water quality from an ecological point of view. International Journal of Environmental Sciences \& Natural Resources 2(2):1-8.

Barinova, S. \& T. Fahima 2017. The development of the world database of freshwater algae-indicators. Journal of Environment and Ecology 8(1): 1-7.

Barinova, S.S., L.A. Medvedeva \& O.V. Anissimova 2006. Diversity of algal indicators in environmental assessment. Pilies Studio, Tel Aviv, 498 pp. (in Russian). [Баринова C.C., Медведева А.А., Анисимова О.В. 2006. Водорослииндикаторы в оценке качества окружающей среды. Тель Авив: Pilies Studio Publisher. 498 с.].

Barinova, S., O. Bilous \& N. Ivanova 2016. New statistical approach to spatial analysis of ecosystem of the Sasyk Reservoir, Ukraine. International Journal of Ecotoxicology and Ecobiology 1(3):118-126.

Barinova, S. \& E. Krupa 2016. Critical environmental factors for photosynthetic organisms of the Shardara Reservoir, Kazakhstan. Bulletin of Advanced Scientific Research 2(5):17-27.

Barinova, S. \& E. Krupa 2017. Bioindication of ecological state and water quality by phytoplankton in the Shardara Reservoir, Kazakhstan. Environment and Ecology Research 5: 73-92.

Barinova, S., E. Krupa \& U. Kadyrova 2017. Spatial dynamics of species richness of phytoplankton of Lake Balkhash (Kazakhstan) in the gradient of abiotic factors. Transylvanian Review of Systematic and Ecological Research 19(2):1-18.

Barinova, S., E. Krupa, V. Tsoy \& L. Ponamareva 2018. The application of phytoplankton in ecological assessment of the Balkhash Lake (Kazakhstan). Applied Ecology and Environmental Research 16(3):2089-2111.

Barinova, S.S. 1988. Polymorphism of connective structures in diatom algae. In: Evolutionary Research. Vavilov's Themes, (V.A. Krassilov, ed.), pp. 110-122., FEB RAS Press, Vladivostok (in Russian). [Баринова С.С. Полиморфизм соединительных структур диатомовых водорослей. Эволюционные исслелования. Вавиловские темы / под. реА. В.А. Красилова. ВАадивосток: Аальневосточное отделение РАН. С. 110-122].
Barinova, S.S., E.G. Krupa, A.A. Protasov \& T.N. Novoselova 2017b. Benthification in the inland water ecosystems of Eurasia, some ecological aspects. MOJ Ecology and Environmental Sciences 2(7):00048.

Berezovikov, N. 2006. Alakol State Nature Reserve. In: Reserves of Central Asia and Kazakhstan. Protected natural areas of Central Asia and Kazakhstan, (R.V. Yaschenko, ed.), pp. 12-29, Tethys, Almaty (in Russian). [Березовиков H. А^акольский государственный заповедник // Заповедники средней Азии и Казахстана / поА реА. Р.В Ященко. Алма-Ата: Thetys. С. 12-29].

Bilous, O.P., S.S. Barinova, N.O. Ivanova \& O.A. Huliaieva 2016. The use of phytoplankton as an indicator of internal hydrodynamics of a large seaside reservoir-case of the Sasyk Reservoir, Ukraine. Ecohydrology and Hydrobiology 16:160-174.

Cavalier-Smith, T. 2004. Only six kingdoms of life. Proceedings of the Royal Society, London B 271:1251-1262.

Guiry, M.D. \& G.M. Guiry 2018. AlgaeBase, World-wide electronic publication. National University of Ireland Press, Galway. Available from: http://www.algaebase.org/. Last accessed 20.06.2018.

Jiyenbekov, A, S. Barinova, A. Bigaliev, S. Nurasov \& E. Sametova 2018. The first evidence about the algae of the protected Alakol lake (Kazakhstan) and their floral analysis. Byulleten' Moskovskogo Obshchestva Ispytatelei Prirody. Biologicheskaya seriya (in press) (in Russian). [Ажиенбеков А., Баринова С., Бигалиев А., Нурашов С., Саметова Е. Первые данные о водорослях заповедника Озеро Алаколь и их флористический анализ // Бюлметень Московского Общества Испытателей Природы, биомогическая серия (в печати)].

Krupa, E.G., S.S Barinova, L. Ponamareva \& V.N. Tsoy 2018. Statistical mapping and 3-D surface plots in phytoplankton analysis of the Balkhash Lake (Kazakhstan). Transylvanian Review of Systematic and Ecological Research 20(1):1-16.

Krupa, E.G., N.A. Amirgalieva, T.Ya. Lopareva, A.K. Isaeva \& B.B. Bimanbaeva 2010. Zooplankton of Lake Alakol and its distribution depending on mineralization and chemical composition of water. Bulletin of the Kazakh National University. Byulleten' Kazakhskogo natsional'nogo universiteta Al-Farabi, Biologicheskaya seriya, Almaty 1(43):96100 (in Russian) [Крупа Е.Г., Амиргалиева Н.А., Аопарева Т.Я., Исаева А.К., Биманбаева Б.Б. Зоопланктон озера Алаколь и его распределение в связи с минерализайией и хомизмом вод / / Бюлметень Казахского Национального Университета А^ь Фараби, биологическая серия, Алматы 1(43):96-100].

Krupa, E.G., S.S. Barinova, K.B. Isbekov \& S.Z. Assylbekova 2018. The use of zooplankton distribution maps for assessment of ecological status of the Shardara reservoir (Southern Kazakhstan). Ecobydrology and Hydrobiology 18(1):52-65.

Novakovsky, A.B. 2004. Abilities and base principles of program module "GRAPHS." (Scientific Reports of Komi Scientific Center, Ural Division of the Russian Academy of Sciences, 27). 28 pp. (in Russian). [Новаковский А.Б. 2004. Возможности и принципы работы программного модуля "GRAPHS" (Автоматизация научных исследований. Сыктывкар, Коми научный центр УрО РАН. Вып. 27). 28 с.].

The Nature Conservancy and World Wildlife Fund (WWF). 2013. Freshwater ecoregions of the world (FEOW). Available from: http://feow.org/. Last accessed 20.06.2018. 
Jiyenbekov et al.

Van Dam, H., A. Mertens \& J. Sinkeldam 1994. A coded checklist and ecological indicator values of freshwater diatoms from the Netherlands. Netherland Journal of Aquatic Ecology 28(1):117-133. 